\title{
A fixed point theorem for a Ćirić-Berinde type mapping in orbitally complete metric spaces
}

\author{
SEONG-HOON CHO
}

\section{ABSTRACT.}

In this paper, we introduce the notion of Ćirić-Berinde type almost set-valued contraction mappings and give a fixed point theorem for these mappings in orbitally complete metric spaces.

Acknowledgements. The author is grateful to Professor Vasile Berinde for providing reference [17] and his usful comments and to anonymous referees for variable comments and suggestions, which improved the paper.

\section{REFERENCES}

[1] Alber, Ya. I. and Guerre-Delabriere, S., Principles of weakly contractive maps in Hilbert spaces, in New Results in Operator Theory (I. Goldberg, Yu. Lyubich Eds.), Advances and Appl., 98, Birkhauser Verlag, 1997, $7-22$

[2] Abbas, M. and Jungck, G., Common fixed point results for noncommuting mappings without continuity in cone metric spaces, J. Math. Anal. Appl., 341 (2008), 416-420

[3] Agarwal, R. P., El-Gebeily, M. A. and O'regan, D., Generalized contractions in partially ordered metric spaces, Appl. Anal., 87 (2008), 1-8

[4] Amini-Harandi, A., Fixed point theory for set-valued quasi-contraction maps in metric spaces, Appl. Math. Lett., 24 (2011), 1791-1794

[5] Banach, S., Sur les operations dans les ensembles abstraits et leur applications aux equations integrales, Fund. Math., 3 (1922), 133-181

[6] Berinde, V., Approximation fixed points of weak contractions using the Picard iteration, Nonlinear Anal. Forum, 9 (2004), No. 1, 43-53

[7] Berinde, V., General contractive fixed point theorems for Ćirić-type almost contractions in metric spaces, Carpathian J. Math., 24 (2008), No. 2, 10-19

[8] Berinde, V., On the approximation of fixed points of weak contractive mappings, Carpathian J. Math., 19 (2003), No. 1, 7-22

[9] Berinde, V., Approximating fixed points of weak $\varphi$-contractions using the Picard iteration, Fixed Point Theory, 4 (2003), No. 2, 131-142

[10] Berinde, V., Iterative approximation of fixed points, 2nd ed., Berlin, Heidelberg, New York, Springer-Verlag, 2007

[11] Berinde, M. and Berinde, V., On a general class of multi-valued weakly Picard mappings, J. Math. Anal. Appl., 326 (2007) 772-782

[12] Berinde, V., Approximating common fixed points of noncommuting discontinuous weakly contractive mappings in metric spaces, Carpathian J. Math., 25 (2009) 13-22

[13] Berinde, V., Some remarks on a fixed point theorem for Ćirić-type almost contractions, Carpathian J. Math., 25 (2009) 157-162

[14] Berinde, V., Common fixed points of noncommuting almost contractions in cone metric spaces, Math Commun, 15 (2010) 229-241

[15] Berinde, V., Approximating common fixed points of noncommuting almost contractions in metric spaces, Fixed Point Theory, 11 (2010) 179-188

Received: 26.06.2012; In revised form: 12.10.2012; Accepted: 12.12 .2012

2010 Mathematics Subject Classification. 47H10, 54H25.

Key words and phrases. Fixed point, Ćirić-Berinde type mapping, Metric space. 
[16] Berinde, V., Common fixed points of noncommuting discontinuous weakly contractive mappings in cone metric spaces, Taiwanese J Math, 14 (2010) 1763-1776

[17] Berinde, V. and Păcurar, M., The role of the Pompeiu-Hausdorff metric in fixed pointntheory, Creat. Math. Inform., 22 (2013) 143-150

[18] Chidume, C. E., Chidume, C. O., Djitte, N. and Minjirbir, M. S., Iterative algorithms for zeros of multivalued nonlinear mappings in Banach spaces, to appear

[19] Chidume, C. E., Chidume, C. O., Djitte, N. and Minjirbir, M. S., Convergence theorems for fixed points of multivalued strictly pseudocontractive mappings in Hilbert spaces, to appear

[20] Chidume, C. E., Chidume, C. O., Djitte, N. and Minjirbir, M. S., Krasnoselskii- type algorithm for fixed points of multivalued strictly pseudocontractive mappings, to appear

[21] Cho, S. H. and Bae, J. S., Common fixed point theorems for mappings satisfying property (E.A) on cone metric spaces, Math. Comput. Modelling, 53 (2011), 945-951

[22] Choudhury, B. S., Unique fixed point theorem for weakly $C$-contractive mappings, Kathmandu University J. Sci. Engg. Tech., 5 (2009), 6-13

[23] Ćirić, L. B., A generalization of Banachs contraction principle, Proc. Amer. Math. Soc., 45 (1974) 267-273

[24] Daffer, P. Z. and Kaneko, H., Fixed points of generalized contractive multi-valued mappings, J. Math. Anal. Appl., 192 (1995), 655-666

[25] Djafari Rouhani, B. and Moradi, S. Common fixed point of multivalued generalized,-weak contractive mappings, Fixed Point Theory Appl., 2010, Article ID 708984, 13 pp

[26] Fang, J. X. and Gao, Y., Common fixed point theorems under strict contractive conditions in Menger spaces, Nonlinear Anal., 70 (2009), 184-193

[27] Huang, L. G. and Zhang, X., Cone metric spaces and fixed point theorems of contractive mappings, J. Math. Anal. Appl., 332 (2007), No. 2, 1468-1476

[28] Ilić, D. and Rakočević, V., Quasi-contraction on cone metric spaces, Appl. Math. Lett., 2008 (2008), doi:10.1016/j.aml.2008.08.001

[29] Kirk, W. A. and Sims, B, (eds.) Handbook of metric fixed point theory, Dordrecht, Kluwer Acad. Publ., 2001

[30] Rezapour, Sh. and Hamlbarani, R., Some notes on the paper "Cone metric spaces and fixed point theorems of contractive mappings", J. Math. Anal. Appl., 345 (2008), 719-724

[31] Yang, S. K., Bae, J. S. and Cho, S. H., Coincidence and common fixed and periodic point theorems in cone metric spaces, Comput. Math. Appl., 61 (2011), No. 2, 170-177

HANSEO UNIVERSITY

DEPARTMENT OF MATHEMATICS

Chungnam, 356-706, SOUTH KOREA

E-mail address: shcho@hanseo.ac.kr 